\title{
Heavy Metal Concentrations of Soil, Rock, and Coal Gangue in the Geological Profile of a Large Open-Pit Coal Mine in China
}

\author{
Xiaoyang Liu ${ }^{1,2}$, Ming Jing ${ }^{3, *}$ and Zhongke Bai ${ }^{1,4, *}$ \\ 1 School of Land Science and Technology, China University of Geosciences (Beijing), Beijing 100083, China; \\ liuxiaoyangsd@163.com \\ 2 Technical Centre for Soil, Agricultural and Rural Ecology and Environment, Ministry of Ecology and \\ Environment, Beijing 100012, China \\ 3 China Natural Resources News, Beijing 100860, China \\ 4 Key Laboratory of Land Consolidation and Rehabilitation, Ministry of Land and Resources, \\ Beijing 100035, China \\ * Correspondence: jingmingnongda@126.com (M.J.); baizk@cugb.edu.cn (Z.B.)
}

Citation: Liu, X.; Jing, M.; Bai, Z. Heavy Metal Concentrations of Soil, Rock, and Coal Gangue in the Geological Profile of a Large Open-Pit Coal Mine in China. Sustainability 2022, 14, 1020. https:/ / doi.org/10.3390/su14021020

Academic Editor: Franco Ajmone Marsan

Received: 5 December 2021 Accepted: 10 January 2022 Published: 17 January 2022

Publisher's Note: MDPI stays neutral with regard to jurisdictional claims in published maps and institutional affiliations.

Copyright: (c) 2022 by the authors. Licensee MDPI, Basel, Switzerland. This article is an open access article distributed under the terms and conditions of the Creative Commons Attribution (CC BY) license (https:// creativecommons.org/licenses/by/ $4.0 /)$.

\begin{abstract}
Risk assessment related to heavy metals in mining areas is crucial to ensuring the sustainable development of regional ecosystems and protecting human health. However, almost all research on the impact of mining activities on environmental quality entails field monitoring of surface soils or soil profiles. Here, to compare the variety of heavy metal concentrations in the geological profile, 39 samples (including soil, rock, and coal gangue) were collected and analyzed from hundreds of meters underground in the Pingshuo coal mine (Anjialing coal mine, Antaibao coal mine, and Donglutian coal mine), which is the largest open-pit coal mine in China. The mean heavy metal concentrations of $\mathrm{Cd}, \mathrm{Hg}$, $\mathrm{As}, \mathrm{Pb}, \mathrm{Cr}, \mathrm{Cu}, \mathrm{Zn}$, and $\mathrm{Ni}$ in soils were $0.15 \mathrm{mg} / \mathrm{kg}, 0.02 \mathrm{mg} / \mathrm{kg}, 13.70 \mathrm{mg} / \mathrm{kg}$, $27.12 \mathrm{mg} / \mathrm{kg}, 70.89 \mathrm{mg} / \mathrm{kg}, 26.10 \mathrm{mg} / \mathrm{kg}, 79.88 \mathrm{mg} / \mathrm{kg}$, and $37.68 \mathrm{mg} / \mathrm{kg}$, respectively; most of these metals were more concentrated in the soil samples than in the rock and coal gangue samples. A potential ecological risk assessment indicated that $\mathrm{As}, \mathrm{Pb}, \mathrm{Cr}, \mathrm{Cu}, \mathrm{Zn}$, and $\mathrm{Ni}$ in all samples showed low risk, while the ecological risk degrees of $\mathrm{Cd}$ and $\mathrm{Hg}$ were higher and contributed most to the total risk index $(R I)$. The highest E_r^i value (92.94) for Cd was found in rock samples, contributing to approximately $55.18 \%$ of the to tal $R I$. For $\mathrm{Hg}$, four rock sampling sites had the highest E_r i values $(427.70,270.78,198.96$, and 188.70), contributing approximately $68.36-88.07 \%$ of the total $R I$. Ranked after soil $(0.15 \mathrm{mg} / \mathrm{kg})$, limestone and shale showed high mean Cd concentrations (both $0.13 \mathrm{mg} / \mathrm{kg}$ ). The highest mean concentration was found in coal gangue samples $(0.1 \mathrm{mg} / \mathrm{kg})$. Compared with the other types of samples, the mean concentrations of $\mathrm{Cr}, \mathrm{Cu}$, and $\mathrm{Ni}$ in soils, limestone, and mudstone were relatively higher. At different sites, heavy metal concentrations varied greatly at different depths, owing to diverse sample types and rock types. Correlations between heavy metals and soil nutrients indicated that $\mathrm{N}$ and $\mathrm{P}$ were closely correlated with heavy metals. Comparing the proportions of different heavy metals in various types of samples showed that heavy metals in soils were extremely similar to those in limestone, mudstone, and shale, implying that soils might indirectly inherit their features from their parent material.
\end{abstract}

Keywords: soil; rock; coal gangue; heavy metal; coal mine

\section{Introduction}

Coal is one of the world's main energy sources, generating $40.4 \%$ of the world's electricity. It has therefore helped greatly with the development of society and the global economy. However, coal mining has a negative impact on the environment [1], especially in developing countries such as China [2]. With greater public awareness of the environment and human health, there has been an increasing interest in studying environmental problems arising from coal-mining areas. 
Heavy metals are commonly found in the soil at various concentrations, owing to the pedogenetic process of weathering of the parent materials. Thus, parent materials are important for explaining changes in soil contamination [3,4]. Wu et al. [5] stated that soil parent materials dominant the concentrations of As and $\mathrm{Cr}$ in soils. Rock metal content is transferred to soils and greatly affects both the properties and trace metals of soils, determining their geochemical and mineralogical characteristics [6,7]. Unsurprisingly, parent rock metal content is transferred to soils, and this has the potential to alter metal concentration and mobility in soils. It is accepted that heavy metal concentrations in soils vary depending on the source material, mainly due to the presence of geochemically unique rocks [8]. Heavy-metal concentrations in soils are directly related to the type of rock that the soil originated from [9]. Rocks and soils are common solid wastes and are produced in large volumes during the process of open-pit coal mining. As they are usually used for backfilling pits and land reclamation, their environmental quality is vital for the regional environment. Currently, there is great interest in the use of natural rocks as soil amendments and nutrient sources because they are environmentally benign and widely available [10]. However, little attention has been paid to the elemental compositions of various fresh parent rocks in relation to cation imbalance and their potential for causing high concentrations of heavy metals in soils [10]. Toxic substances in coal gangue and rocks might migrate into recultivated soils, which might pollute soil [11-13] and threaten ecological environment and human health [14,15].

However, studies into changes in heavy-metal concentrations in the geological profile up to depths of hundreds of meters underground are still limited. Therefore, the objectives of this study were to: (1) compare differences in heavy-metal concentrations between soil, rock, and coal gangue and between different rock types at different depths; (2) assess the potential ecological risk of various types of samples; and (3) compare the proportions of different heavy metals after data normalization.

\section{Materials and Methods}

\subsection{Study Area}

Pingshuo coal mine, located in the northeastern Loess Plateau, is the largest open-pit coal mine in China. It covers an area of approximately $380 \mathrm{~km}^{2}$. This region has a typical temperate arid to semi-arid continental monsoon climate. The mean annual temperature is $4.8-7.8^{\circ} \mathrm{C}$, and the mean annual precipitation is $428.2-449.0 \mathrm{~mm}$. The soils in this zone are mainly chestnut soil and loessial soil, which are characterized by their low content of organic matter. Pingshuo coal mine consists of three mining areas: the Anjialing coal mine, Antaibao coal mine, and Donglutian coal mine. In this study, they were all chosen as specific study objectives; the sampling sites in these three coal mines are shown in Figure 1. 

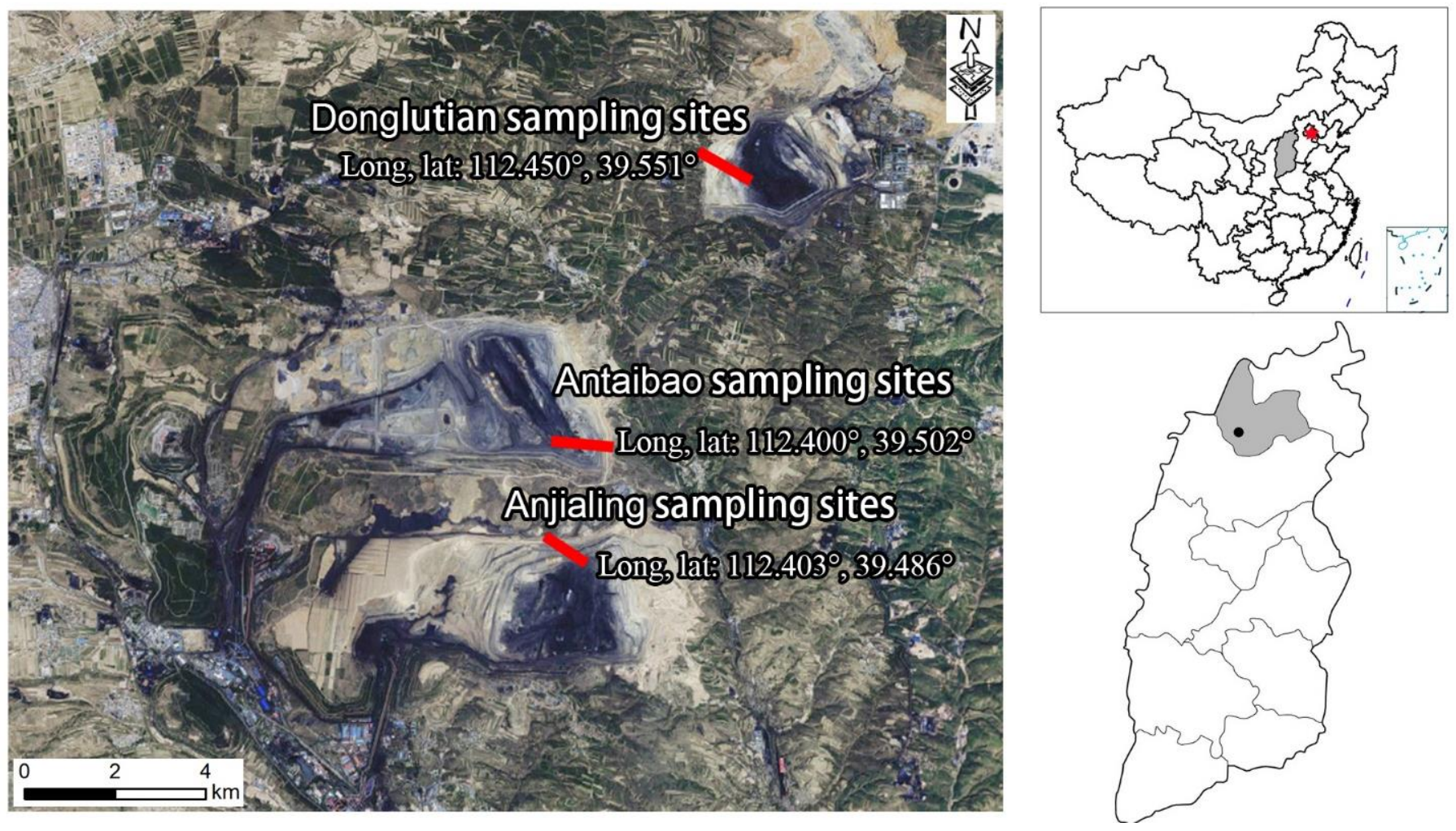

Figure 1. Study area and sampling sites of rock and soil in the mining pits.

\subsection{Soil Sampling and Analysis}

In August 2017, we collected 39 samples of soil, rock, and coal gangue in the mining pits of the Anjialing, Antaibao, and Donglutian coal mines, using either a rock pitch hammer or soil auger (Figure 2). The positions of all the sampling sites were acquired by a handheld global positioning system, recording the longitude, latitude, and altitude. After sampling, the samples were sealed in clean polyethylene bags and labeled. Samples were then ground and sieved through a 2-mm sieve and transported to a laboratory for further analysis. The analysis of soil fertility properties followed the standard methods described in Lu [16]. Briefly, soil $\mathrm{pH}$ was measured in soil slurry (1:2.5, soil: distilled water) with a $\mathrm{pH}$ meter. Soil organic matter (SOM) was determined by the potassium dichromate oxidation method. Total-N analysis followed the Kjeldahl digestion method. Total $\mathrm{P}$ was determined by the molybdate-blue colorimetric method. Total $\mathrm{K}$ was determined by the sodium-hydroxide melting-flame photometric method. Eight heavy metals ( $\mathrm{Cd}, \mathrm{Hg}$, $\mathrm{As}, \mathrm{Pb}, \mathrm{Cr}, \mathrm{Cu}, \mathrm{Ni}$, and $\mathrm{Zn}$ ) were measured using inductively coupled plasma mass spectrometry (7900, Thermo Electron Corporation, Waltham, MA, USA, with the detection limit of $0.01 \mu \mathrm{g} / \mathrm{g}$ ). The specific operation process followed that used in an previous study [17]. 

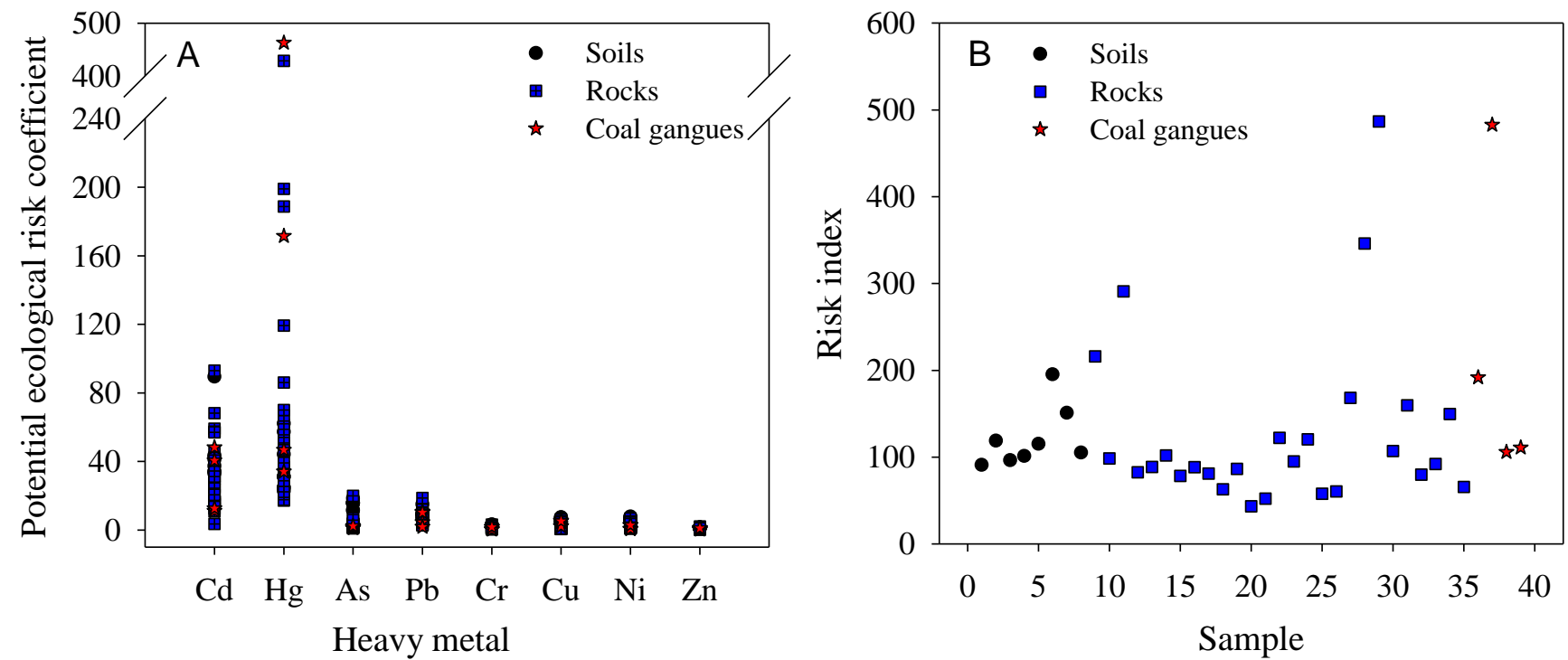

Heavy metal

Figure 2. Potential ecological risk assessment of different samples. A shows the potential ecological risk coefficients of the referred heavy metals, and B shows the risk indexes of the samples.

\subsection{Potential Ecological Risk Analysis}

The potential ecological risk index (RI) proposed by Hakanson [18] is applied to determine the ecological risks of heavy metals in the environment. The method fully takes into account the potential effects of heavy metals on ecosystems and can be used to assess sediments and soil in large regional areas [19]. Here, the Hakanson potential ecological RI was calculated by the following equations:

$$
\begin{aligned}
& P_{i}=C_{d}^{i} / C_{r}^{i}, P=\sum_{i=1}^{m} P_{i} \\
& E_{f}^{i}=T_{f}^{i} P_{i}, R I=\sum_{i=1}^{m} E_{f}^{i}
\end{aligned}
$$

where $C_{d}^{i}$ is the measured heavy metal concentration; $C_{r}^{i}$ is the background level. In this research, the background levels of heavy metals in Shanxi Province were adopted. $T_{f}^{i}$ is the toxic response factor of the heavy metal $I ; E_{f}^{i}$ is the individual potential ecological $R I$ of the heavy metal $I$; and $R I$ is the potential ecological risk of the heavy metal. The toxic response factors were considered to be $\mathrm{Cd}=30, \mathrm{Hg}=40, \mathrm{As}=10, \mathrm{Cu}=\mathrm{Pb}=\mathrm{Ni}=5$, $\mathrm{Cr}=2$, and $\mathrm{Zn}=1[20,21]$. Classification criteria of the potential ecological risk index is given in Table 1 .

Table 1. Classification criteria of the potential ecological $R I$.

\begin{tabular}{cccc}
\hline $\boldsymbol{E}_{f}^{i}$ & Risk Classification & $\boldsymbol{R I}$ & Risk Classification \\
\hline$<40$ & Low risk & $<150$ & Low risk \\
$40-80$ & Moderate risk & $150-300$ & Moderate risk \\
$80-160$ & Considerable risk & $300-600$ & Considerable risk \\
$160-320$ & High risk & $\geq 600$ & High risk \\
$\geq 320$ & Very high risk & & \\
\hline
\end{tabular}




\subsection{Statistical Analysis}

Descriptive statistics of the analyzed soil data were determined using SPSS 19.0 software (IBM, Armonk, NY, USA). The Pearson correlation test was applied to test the possible relationships between heavy metals and soil chemical properties. The concentration spectra of heavy metals in various samples were then plotted after data normalization using the min-max scaling method.

\section{Results and Discussion}

\subsection{Descriptive Statistics of Heavy Metals of Soil, Rock, and Coal Gangue}

The heavy-metal concentrations of the soil, rock, and coal gangue samples are presented in Table 2. The mean heavy-metal concentrations of the soil samples showed a trend of $\mathrm{Zn}(79.88 \mathrm{mg} / \mathrm{kg})>\mathrm{Cr}(70.89 \mathrm{mg} / \mathrm{kg})>\mathrm{Ni}(37.68 \mathrm{mg} / \mathrm{kg})>\mathrm{Pb}(27.12 \mathrm{mg} / \mathrm{kg})>\mathrm{Cu}$ $(26.10 \mathrm{mg} / \mathrm{kg})>$ As $(13.70 \mathrm{mg} / \mathrm{kg})>\mathrm{Cd}(0.15 \mathrm{mg} / \mathrm{kg})>\mathrm{Hg}(0.02 \mathrm{mg} / \mathrm{kg})$. Compared with the background metal values of soil samples from Shanxi province (Shi et al., 1994), the mean heavy-metal concentrations of the soil samples in our study were relatively high, except in the case of $\mathrm{Hg}$. The highest coefficient of variation (CV) in the soil samples was found for $\mathrm{Hg}(50 \%)$, followed by $\mathrm{Cd}(40 \%)$, indicating relatively more variation in these metal elements. This result agrees with a study conducted in India by Vinod et al. (2019). The rock samples showed a similar trend regarding their mean heavy-metal concentrations (except the rank of $\mathrm{Pb}>\mathrm{Ni}$ ). Compared with soils, lower concentrations were found in rocks for most metals (except $\mathrm{Hg}$ ), which may be attributed to the fact that underground rocks receive less interference from mining activities than upper soils. A similar result was reported by Wang et al. (2004) [22], who showed that $\mathrm{Cd}, \mathrm{Pb}, \mathrm{Cu}$, and $\mathrm{Zn}$ in soils obviously exceeded those in rocks in a $\mathrm{Pb}-\mathrm{Zn}$ mine. However, the $\mathrm{CVs}$ in rocks were higher and covered a much wider range (39.99-104.52\%). In particular, the CVs of $\mathrm{Hg}$ and As both exceeded $100 \%$, demonstrating strong variation in heavy-metal concentrations in rocks. In rocks, all of the heavy metals except $\mathrm{Zn}$ recorded kurtosis values greater than zero, and all of the heavy metals except $\mathrm{Zn}$ and $\mathrm{Ni}$ recorded skewness values above one, suggesting right-handed skewness and leptokurtic kurtosis. Compared with the soil and rock samples, the coal gangue samples exhibited lower mean concentrations for most heavy metals and had a wider CV range (29.49-110.00\%). This indicates the uneven distribution of heavy metals in coal gangue. Comparable heavy metal and $\mathrm{CV}$ values were also reported in nine coal mines in Shanxi Province [23].

Table 2. Descriptive statistics of heavy-metal concentrations in different types of samples.

\begin{tabular}{ccccccccc}
\hline Samples & $\begin{array}{c}\text { Heavy } \\
\text { Metals }\end{array}$ & $\begin{array}{c}\text { Mean } \\
(\mathbf{m g} / \mathbf{k g})\end{array}$ & $\begin{array}{c}\text { Min. } \\
(\mathbf{m g} / \mathbf{k g})\end{array}$ & $\begin{array}{c}\text { Max. } \\
(\mathbf{m g} / \mathbf{k g})\end{array}$ & Std. & CV & Kurtosis & Skewness \\
\hline & $\mathrm{Cd}$ & 0.15 & 0.11 & 0.30 & 0.06 & $40.00 \%$ & 6.86 & 2.56 \\
& $\mathrm{Hg}$ & 0.02 & 0.01 & 0.04 & 0.01 & $50.00 \%$ & -1.02 & 0.84 \\
Soils & $\mathrm{As}$ & 13.70 & 10.26 & 16.77 & 2.17 & $15.84 \%$ & -0.06 & -0.69 \\
$(\mathrm{~N}=8)$ & $\mathrm{Pb}$ & 27.12 & 19.45 & 43.97 & 7.51 & $27.69 \%$ & 4.34 & 1.82 \\
& $\mathrm{Cr}$ & 70.89 & 59.99 & 87.96 & 9.61 & $13.56 \%$ & 0.08 & 1.06 \\
& $\mathrm{Cu}$ & 26.10 & 21.59 & 33.87 & 5.28 & $20.23 \%$ & -1.64 & 0.72 \\
& $\mathrm{Ni}$ & 37.68 & 28.13 & 46.47 & 6.54 & $17.36 \%$ & -1.23 & 0.01 \\
& $\mathrm{Zn}$ & 79.88 & 64.49 & 95.95 & 10.48 & $13.12 \%$ & -0.66 & 0.06 \\
\hline \multirow{2}{*}{ Rocks } & $\mathrm{Cd}$ & 0.10 & 0.01 & 0.32 & 0.07 & $70.00 \%$ & 1.78 & 1.37 \\
$(\mathrm{~N}=27)$ & $\mathrm{Hg}$ & 0.05 & 0.01 & 0.25 & 0.05 & $100.00 \%$ & 7.63 & 2.67 \\
& $\mathrm{As}$ & 3.10 & 0.85 & 18.15 & 3.24 & $104.52 \%$ & 19.27 & 4.16 \\
& $\mathrm{~Pb}$ & 22.10 & 8.05 & 54.85 & 9.63 & $43.57 \%$ & 3.96 & 1.39 \\
& $\mathrm{Cr}$ & 33.46 & 10.04 & 89.44 & 17.77 & $53.11 \%$ & 3.22 & 1.76 \\
& $\mathrm{Cu}$ & 9.41 & 2.73 & 28.72 & 7.48 & $79.49 \%$ & 1.01 & 1.52 \\
& $\mathrm{Ni}$ & 15.66 & 5.61 & 40.15 & 9.13 & $58.30 \%$ & 0.45 & 1.02 \\
& $\mathrm{Zn}$ & 73.96 & 11.10 & 124.50 & 29.58 & $39.99 \%$ & -0.39 \\
\hline
\end{tabular}


Table 2. Cont.

\begin{tabular}{|c|c|c|c|c|c|c|c|c|}
\hline \multirow{8}{*}{$\begin{array}{c}\text { Coal } \\
\text { gangues } \\
(\mathrm{N}=4)\end{array}$} & $\mathrm{Cd}$ & 0.10 & 0.04 & 0.16 & 0.06 & $60.00 \%$ & -5.18 & 0.13 \\
\hline & $\mathrm{Hg}$ & 0.10 & 0.02 & 0.27 & 0.11 & $110.00 \%$ & 1.84 & 1.48 \\
\hline & As & 1.56 & 1.05 & 2.17 & 0.46 & $29.49 \%$ & 1.72 & 0.64 \\
\hline & $\mathrm{Pb}$ & 20.19 & 5.39 & 31.48 & 12.85 & $63.65 \%$ & -4.09 & -0.33 \\
\hline & $\mathrm{Cr}$ & 28.72 & 5.83 & 48.83 & 22.55 & $78.52 \%$ & -5.49 & -0.08 \\
\hline & $\mathrm{Cu}$ & 17.17 & 10.01 & 25.01 & 8.28 & $48.22 \%$ & -5.86 & 0.02 \\
\hline & $\mathrm{Ni}$ & 10.59 & 2.99 & 17.81 & 8.04 & $75.92 \%$ & -5.84 & -0.02 \\
\hline & $\mathrm{Zn}$ & 44.54 & 15.03 & 69.79 & 26.64 & $59.81 \%$ & -4.44 & -0.20 \\
\hline
\end{tabular}

\subsection{Potential Ecological Risk Assessment of Soil, Rock, and Coal Gangue Samples}

The potential ecological index is used to assess the ecological risk of heavy metals in soils and sediments quantitatively [5]. However, there is little research on the potential ecological risk assessment of rocks and coal gangues in mines. Large amounts of heavy metals in heavy-metal-rich native rocks can enter soils during intense chemical weathering processes of rocks, posing great potential ecological risks to the surrounding ecosystem [24,25]. In this study, the potential ecological coefficients $\left(E_{r}^{i}\right)$ of soils, rocks, and coal gangues, and the risk index of each sample, are illustrated in Figure 2. As shown, the RI for eight heavy metals in the soil sampling points ranged from 90.88 to 195.29 (Figure 2B). Specifically, low ecological risk $(R I<150)$ and moderate ecological risk $(150<R I<300)$ accounted for $75 \%$ (six points) and $25 \%$ (two points), respectively. Compared with soils from a typical Chinese agricultural county [26], within which $60 \%$ of the sampling points presented moderate ecological risks, the soil samples in our study showed lower ecological risk. The rock samples showed greater variation in their RI values, with a range of 43.54-486.75. In total, $77.78 \%$ of the samples (21 points) were classified as having low ecological risk. Four and two rock samples were classified as having moderate and considerable ecological risk $(300<R I<600)$, respectively. This result indicates that most of the rocks in this area pose a low ecological risk to the ecosystem. Of the four coal gangue samples, two had $R I$ values below 150 (low ecological risk); one had a moderate ecological risk; and one had a considerable ecological risk. Ni et al. (2009) [27] also found significant enrichment of heavy metals from rocks to soils in the carbonate region of Beijing, China. With their higher clay content, which is responsible for the adsorption of heavy metals, soils tend to have a higher potential ecological risk than rocks and coal gangues.

The statistics of $E_{r}^{i}$ for eight heavy metals are shown in Figure 2A. The $E_{r}^{i}$ values of $\mathrm{Cd}$ and $\mathrm{Hg}$ were significantly high in all samples and contributed the most to the total $R I$. For Cd, four soil samples, seven rock samples, and two coal gangue samples had $E_{r}^{i}$ values exceeding 40. Jiang et al. (2014) [28] also found Cd to be the key influencing factor for the potential ecological risk of soils around a coal gangue dump. The highest $E_{r}^{i}$ value (92.94) for Cd was found in a rock sample; this represents approximately $55.18 \%$ of the contribution to the total RI. For $\mathrm{Hg}$, four rock-sampling sites had high $E_{r}^{i}$ values $(427.70,270.78,198.96$, and 188.70), classifying them into the high-risk level. These samples contributed approximately $68.36-88.07 \%$ to the total $R I$. Moderate-risk $\left(40 \leq E_{r}^{i} \leq 80\right)$ sites and considerable-risk $\left(80 \leq E_{r}^{i} \leq 160\right)$ sites of rock samples accounted for $37.04 \%$ (ten samples) and $7.41 \%$ of the total rock samples, respectively. High $E_{r}^{i}$ values for $\mathrm{Hg}$ in soils and rocks can also be observed in Figure 2A, e.g., one rock sample had an $E_{r}^{i}$ value of 463.30 and contributed $95.96 \%$ to the total $R I$; three soil samples were classified as having a moderate risk, with $E_{r}^{i}$ values of $44.17,57.22$, and 62.09 , respectively. The other six heavy metals this study examined showed low risk in all samples, with $E_{r}^{i}$ values below 40 . The high $\mathrm{Hg}$ and $\mathrm{Cd}$ ecological risks for both soils and rocks are in agreement with previous research on soils [29,30], sediments [31,32], and lakes [33-35]. 


\subsection{Changes in Heavy-Metal Concentrations in Various Samples and at Different Depths}

The rock samples in this study (27 sites) comprised six rock types: granite $(\mathrm{N}=1)$, limestone $(\mathrm{N}=3)$, mudstone $(\mathrm{N}=2)$, sandstone $(\mathrm{N}=9)$, diorite $(\mathrm{N}=3)$, and shale $(\mathrm{N}=9)$. To analyze the changes in heavy-metal concentrations in different types of rocks, soil, and coal gangues, the mean heavy-metal concentrations of different samples were compared, as shown in Figure 3. The highest concentration of $\mathrm{Cd}$ was found in soil samples, with a mean of $0.15 \mathrm{mg} / \mathrm{kg}$. Limestone and shale also showed high Cd concentrations; both had a mean concentration of $0.13 \mathrm{mg} / \mathrm{kg}$. Zhao et al. (2015) [36] reviewed soil contamination in China and also found that soils developed from limestone tended to accumulate much higher Cd concentrations than others. He et al. (2006) [37] compared heavy-metal concentrations between soils developed from various parent materials and concluded that $\mathrm{Cd}$ easily accumulated in soils derived from limestone and shale. Zhu et al. (2019) [38] found that fine mudstone (containing silt and clay) retains organic matter and $\mathrm{Fe}_{2} \mathrm{O}_{3}$ and therefore can incorporate heavy metals through complexation. However, in our study, mudstone was found to have a low $\mathrm{Cd}$ concentration $(0.05 \mathrm{mg} / \mathrm{kg})$. The difference mainly results from the different natures and exposure situations of mudstone. $\mathrm{Hg}$ exhibited different characteristics in its mean concentrations than $\mathrm{Cd}$. The highest mean concentration $(0.1 \mathrm{mg} / \mathrm{kg})$ was found in coal gangue, whereas soil and diorite samples had low mean concentrations $(0.02 \mathrm{mg} / \mathrm{kg}$ and $0.01 \mathrm{mg} / \mathrm{kg}$, respectively). High $\mathrm{Hg}$ concentrations $(0.3 \mathrm{mg} / \mathrm{kg}-6.3 \mathrm{mg} / \mathrm{kg})$ in coal gangue were also found by Niu et al. (2017) [39]. Similar to $\mathrm{Cd}$, elevated concentrations of As were also observed in soil $(0.74 \mathrm{mg} / \mathrm{kg})$ and limestone $(0.42 \mathrm{mg} / \mathrm{kg})$. This result is higher than the As concentrations measured in Ewekoro limestone from Southwestern Nigeria [40]. The other samples had lower or comparable As concentrations, ranging from $1.56 \mathrm{mg} / \mathrm{kg}$ to $2.83 \mathrm{mg} / \mathrm{kg}$. Limestone was also found to be enriched with $\mathrm{Pb}(32.94 \mathrm{mg} / \mathrm{kg})$. Comparable Pb concentrations $(0.37 \mathrm{mg} / \mathrm{kg}-0.46 \mathrm{mg} / \mathrm{kg})$ were found in granite, mudstone, shale, and soil. The distribution characteristics of the mean concentrations of $\mathrm{Cr}, \mathrm{Cu}$, and $\mathrm{Ni}$ in different samples were similar (Figure 3C,D). There were elevated concentrations in soils, limestone, and mudstone and lower concentrations in granite and diorite. Compared with other samples, including sediments and sandstones, lower concentrations of $\mathrm{Cr}$ and $\mathrm{Ni}$ were also found in the granite of Hunan province, China [41]. Shale had the highest $\mathrm{Zn}$ concentration $(85.74 \mathrm{mg} / \mathrm{kg})$ in all samples, whereas limestone, sandstone, and soil had similar $\mathrm{Zn}$ concentrations to shale.

The distribution of heavy metals may differ owing to discontinuous geological conditions [42]. To compare the differences in heavy-metal concentrations in the geological sections of the Anjialing, Antaibao, and Donglutian coal mines, heavy-metal concentrations at different depths are shown in Figure 4. Heavy-metal concentrations varied greatly at different sample sites with various depths, because of the diverse sample types and rock types. Similar results were also found in groundwater by Qiao et al. (2020) [43]. For Cd, higher concentrations were found at elevations of $1271 \mathrm{~m}(0.20 \mathrm{mg} / \mathrm{kg}), 1182 \mathrm{~m}(0.23 \mathrm{mg} / \mathrm{kg})$, and $1204 \mathrm{~m}(0.32 \mathrm{mg} / \mathrm{kg})$ in the three coal mines, with the sample types of limestone, shale, and soil, respectively. $\mathrm{Hg}$ concentrations varied between $0.01 \mathrm{mg} / \mathrm{kg}-0.04 \mathrm{mg} / \mathrm{kg}$ in the Antaibao coal mine, whereas they fluctuated in the Anjialing and Donglutian coal mines, with their highest concentrations of $0.27 \mathrm{mg} / \mathrm{kg}$ and $0.25 \mathrm{mg} / \mathrm{kg}$ at depths of $1268 \mathrm{~m}$ and $1236 \mathrm{~m}$, respectively. The corresponding sample types were coal gangue and shale. Nine samples, at depths of $1428 \mathrm{~m}, 1382 \mathrm{~m}$, and $1272 \mathrm{~m}$ in the Anjialing coal mine; $1287 \mathrm{~m}$ and $1282 \mathrm{~m}$ in the Antaibao coal mine; and at $1381 \mathrm{~m}, 1374 \mathrm{~m}$, and $1321 \mathrm{~m}$ in the Donglutian coal mine, had particularly high As concentrations (Figure 4C). Of these nine samples, one was shale and eight were soils, indicating their As enrichment. Compared with samples in the Anjialing and Antaibao coal mines, samples in the Donglutian coal mine showed higher concentrations of $\mathrm{Pb}$, with values of $54.9 \mathrm{mg} / \mathrm{kg}$ and $44.0 \mathrm{mg} / \mathrm{kg}$ at $1254 \mathrm{~m}$ (shale) and $1321 \mathrm{~m}$ (soil) depths, respectively. The high concentrations of $\mathrm{Cr}, \mathrm{Cu}, \mathrm{Ni}$, and $\mathrm{Zn}$ in the three coal mines were comparable, and some of these samples with high concentrations had the same depths. For example, the concentrations of $\mathrm{Cr}, \mathrm{Cu}$, and $\mathrm{Ni}$ at depths of $1287 \mathrm{~m}$, $1282 \mathrm{~m}$, and $1153 \mathrm{~m}$ in the Antaibao coal mine were higher than those at other sampling 
sites; $\mathrm{Cr}$ and $\mathrm{Zn}$ were present at a depth of $1378 \mathrm{~m}$ (sandstone) in theAnjialing coal mine at concentrations of $89.4 \mathrm{mg} / \mathrm{kg}$ and $119 \mathrm{mg} / \mathrm{kg}$, respectively; these were the highest concentrations of these metals in all samples. These results indicate that the variations in the vertical distribution of heavy metals in the geological profiles of three coal mines were mostly attributed to the sample types collected.
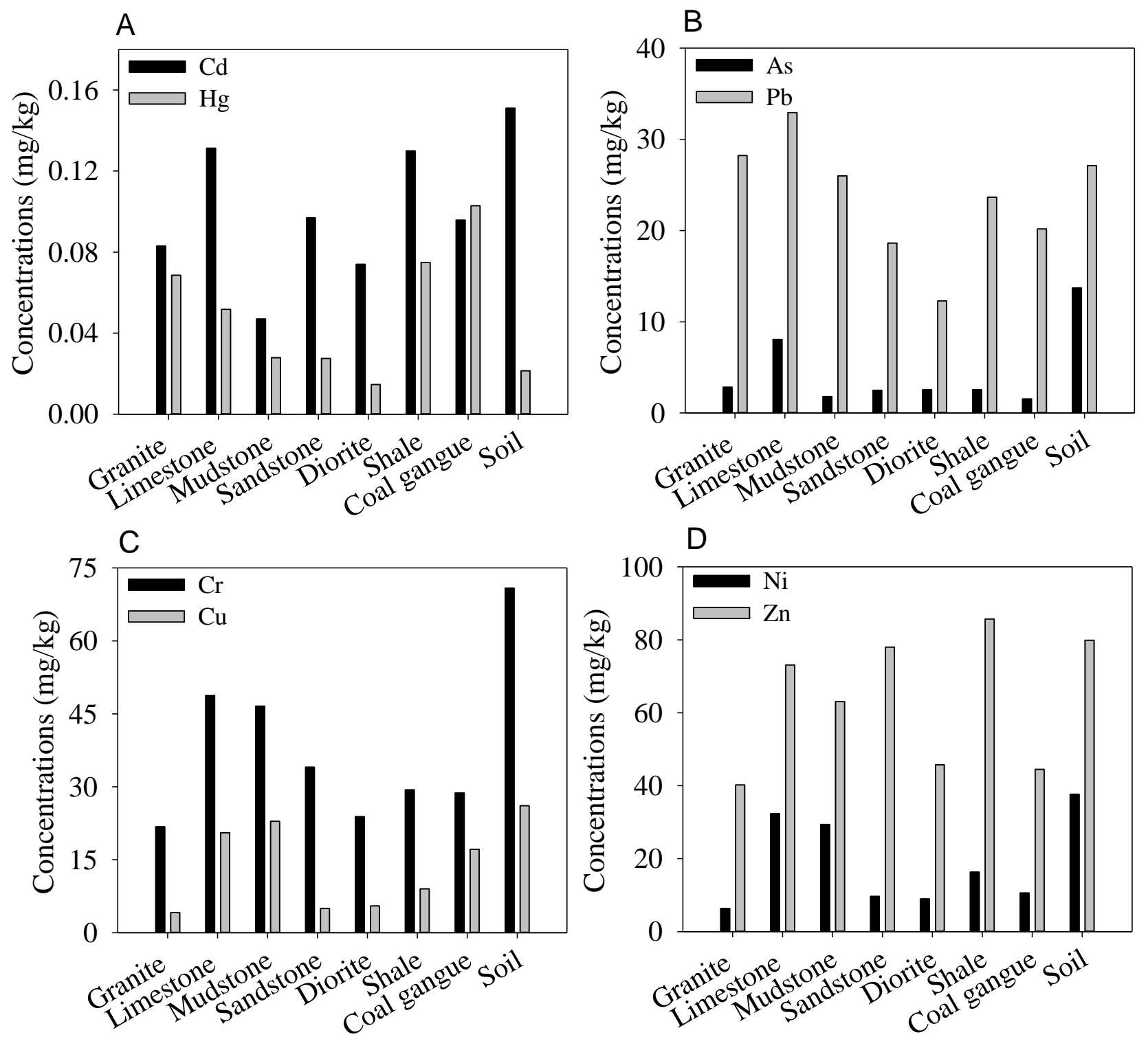

Figure 3. Comparison of heavy-metal concentrations in different samples. (A-D) show the concentrations of different heavy metals in various kinds of samples. 


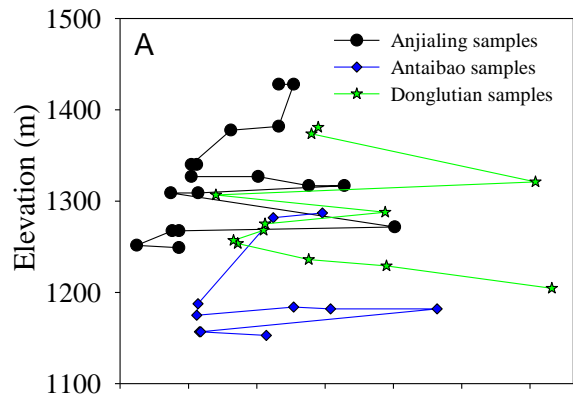

$\begin{array}{lllllll}0.00 & 0.05 & 0.10 & 0.15 & 0.20 & 0.25 & 0.30\end{array}$

Cd concentration $(\mathrm{mg} / \mathrm{kg})$

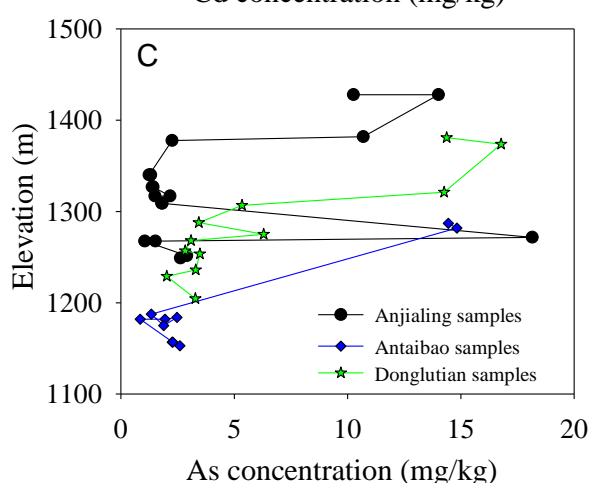

As concentration $(\mathrm{mg} / \mathrm{kg})$
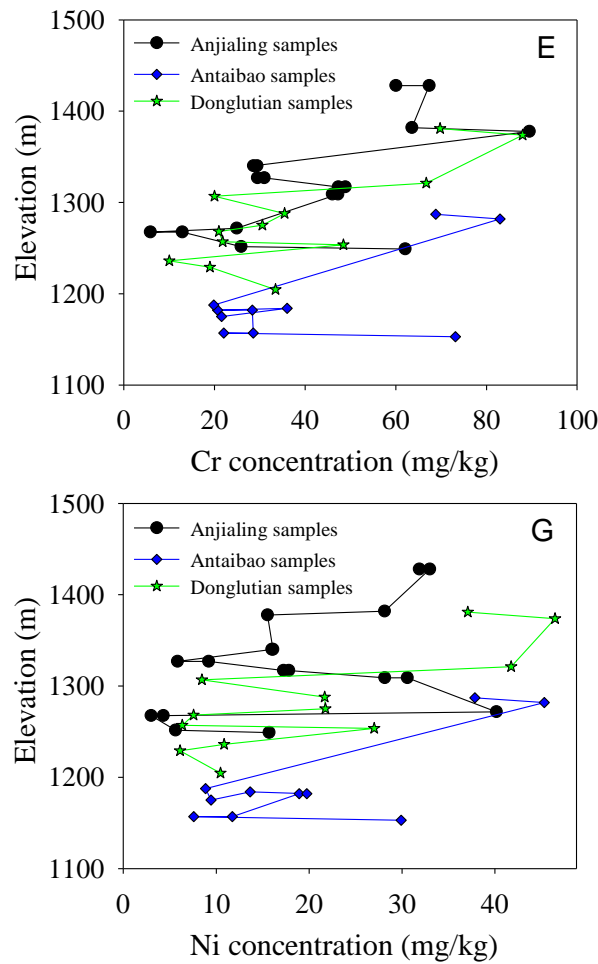
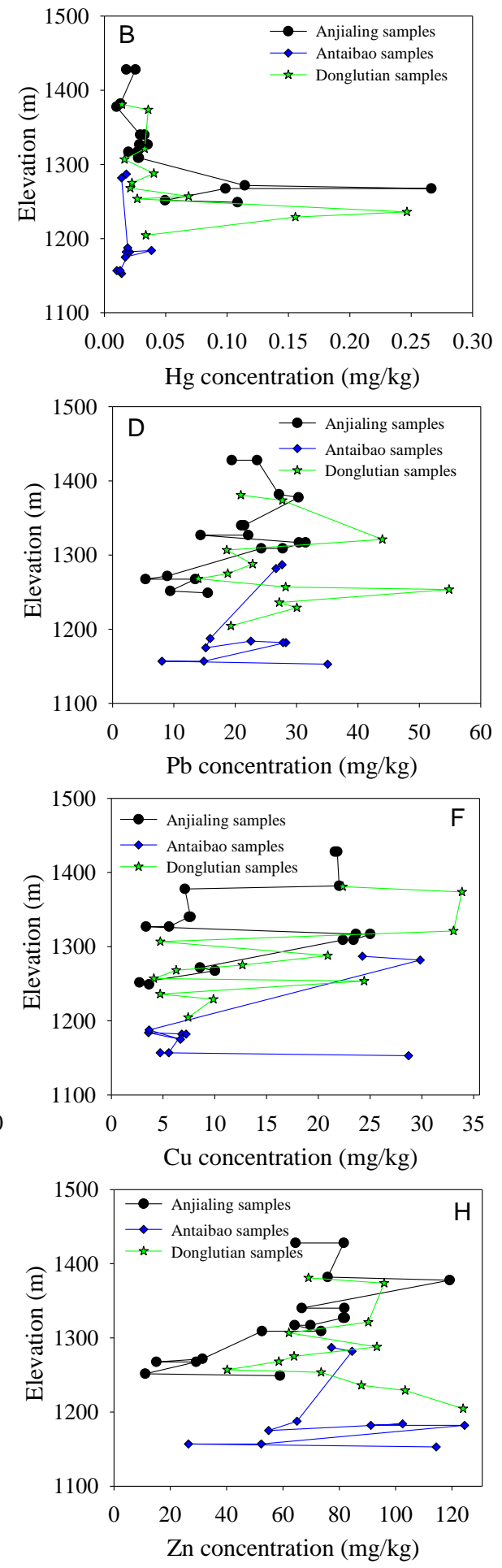

Figure 4. Changes in heavy-metal concentrations at different depths. (A-H) show the concentration changes of $\mathrm{Cd}, \mathrm{Hg}, \mathrm{As}, \mathrm{Pb}, \mathrm{Cr}, \mathrm{Cu}, \mathrm{Zn}$ and $\mathrm{Ni}$ at different depths, respectively.

\subsection{Correlation between Heavy Metals and Soil Nutrients}

Heavy metals and nutrient parameters are crucial indexes of soils and rocks. Some studies have found positive correlations between soil nutrient properties, $\mathrm{pH}$ values, and heavy metals in soil [44,45]. In this study, we explored their correlations in soils, rocks, and gangues; the results of Pearson correlation analysis are shown in Table 3. 
Table 3. Correlation coefficients between heavy metals and soil chemical parameters.

\begin{tabular}{|c|c|c|c|c|c|c|c|c|}
\hline & $\mathrm{Cd}$ & $\mathrm{Hg}$ & As & $\mathbf{P b}$ & $\mathrm{Cr}$ & $\mathrm{Cu}$ & $\mathrm{Ni}$ & $\mathrm{Zn}$ \\
\hline $\mathrm{Cd}$ & 1 & & & & & & & \\
\hline $\mathrm{Hg}$ & 0.16 & 1 & & & & & & \\
\hline As & 0.38 * & -0.04 & 1 & & & & & \\
\hline $\mathrm{Pb}$ & 0.30 & 0.00 & 0.09 & 1 & & & & \\
\hline $\mathrm{Cr}$ & 0.10 & -0.33 & $0.58^{* *}$ & 0.41 * & 1 & & & \\
\hline $\mathrm{Cu}$ & 0.28 & -0.25 & $0.63^{* *}$ & $0.58^{* *}$ & $0.75^{* *}$ & 1 & & \\
\hline $\mathrm{Ni}$ & 0.32 & -0.18 & $0.82^{* *}$ & 0.38 * & $0.74^{* *}$ & $0.87^{* *}$ & 1 & \\
\hline $\mathrm{Zn}$ & $0.56^{* *}$ & -0.01 & -0.06 & $0.52 * *$ & 0.33 & 0.25 & 0.15 & 1 \\
\hline $\mathrm{pH}$ & 0.22 & -0.09 & 0.26 & 0.30 & 0.22 & 0.32 & $0.35 *$ & 0.28 \\
\hline SOM & 0.28 & 0.18 & 0.16 & 0.04 & -0.08 & 0.09 & 0.23 & -0.04 \\
\hline $\mathrm{N}$ & 0.30 & 0.08 & $0.46^{* *}$ & 0.14 & 0.16 & 0.36 * & $0.56^{* *}$ & -0.07 \\
\hline $\mathrm{P}$ & 0.26 & -0.27 & $0.51^{* *}$ & 0.17 & $0.49 * *$ & $0.49^{* *}$ & $0.53^{* *}$ & 0.14 \\
\hline K & -0.08 & $-0.46^{* *}$ & 0.03 & 0.33 & 0.38 * & 0.30 & 0.27 & 0.38 * \\
\hline
\end{tabular}

${ }^{*}$ indicates a significant correlation and $p<0.05 .{ }^{* *}$ indicates a significant correlation and $p<0.01$.

$\mathrm{As}, \mathrm{Pb}, \mathrm{Cr}, \mathrm{Cu}$, and $\mathrm{Ni}$ showed several correlations with each other. Specifically, As was significantly correlated with $\mathrm{Cr}, \mathrm{Cu}$, and $\mathrm{Ni}$ at $p<0.01$. Pb showed significant correlation with $\mathrm{Cu}$ at $p<0.01$ and with $\mathrm{Cr}$ and $\mathrm{Ni}$ at $p<0.05$. Cr also showed significant correlations with $\mathrm{Cu}$ and $\mathrm{Ni}$ at $p<0.01$, and $\mathrm{Cu}$ was significantly related to $\mathrm{Ni}$ at $p<0.01$. Additionally, the pairs of $\mathrm{Cd}$ vs. $\mathrm{Zn}, \mathrm{Cd}$ vs. As, and $\mathrm{Zn}$ vs. Pb were also found to be significantly correlated $(p<0.01$ or $p<0.05)$, implying their common sources [46]. Hg was the only metal in this study that had no significant $(p<0.05)$ correlations with other heavy metals. Zhang et al. (2020) [42] also found that significant correlations $(p<0.01)$ existed among all five heavy metals (except $\mathrm{Hg}$ ) in surface sediments of the Subei Shoal, China.

In the correlation analysis between heavy metals and chemical parameters, $\mathrm{N}$ and $\mathrm{P}$ were found to be closely correlated with heavy metals, e.g., significant and positive correlations were found to exist between $\mathrm{N}, \mathrm{P}, \mathrm{As}, \mathrm{Cu}$, and $\mathrm{Ni}$ at $p<0.01$ or $p<0.05$; $\mathrm{P}$ was significantly correlated with $\mathrm{Cr}$ at $p<0.01$. Additionally, $\mathrm{K}$ and $\mathrm{pH}$ also exhibited significant correlations with heavy metals, with three pairs ( $\mathrm{K}$ vs. Hg, K vs. Cr, and $\mathrm{K}$ vs. Zn) and one pair ( $\mathrm{pH}$ vs. $\mathrm{Ni}$ ) of significant correlations for $\mathrm{K}$ and $\mathrm{pH}$, respectively. In contrast with previous studies [47], we found that SOM had no significant correlations with heavy metals in this study; this may be attributed to the coal gangue being enriched in soil organic $C$, which would influence the accurate determination of SOM.

\subsection{Proportional Comparison of Different Heavy Metals in Various Types of Samples}

To compare the proportion of heavy metals in different samples, the sum values of the eight heavy metals and individual heavy metals in various samples after data normalization were drawn and compared using the min-max scaling method (Figure 5). 


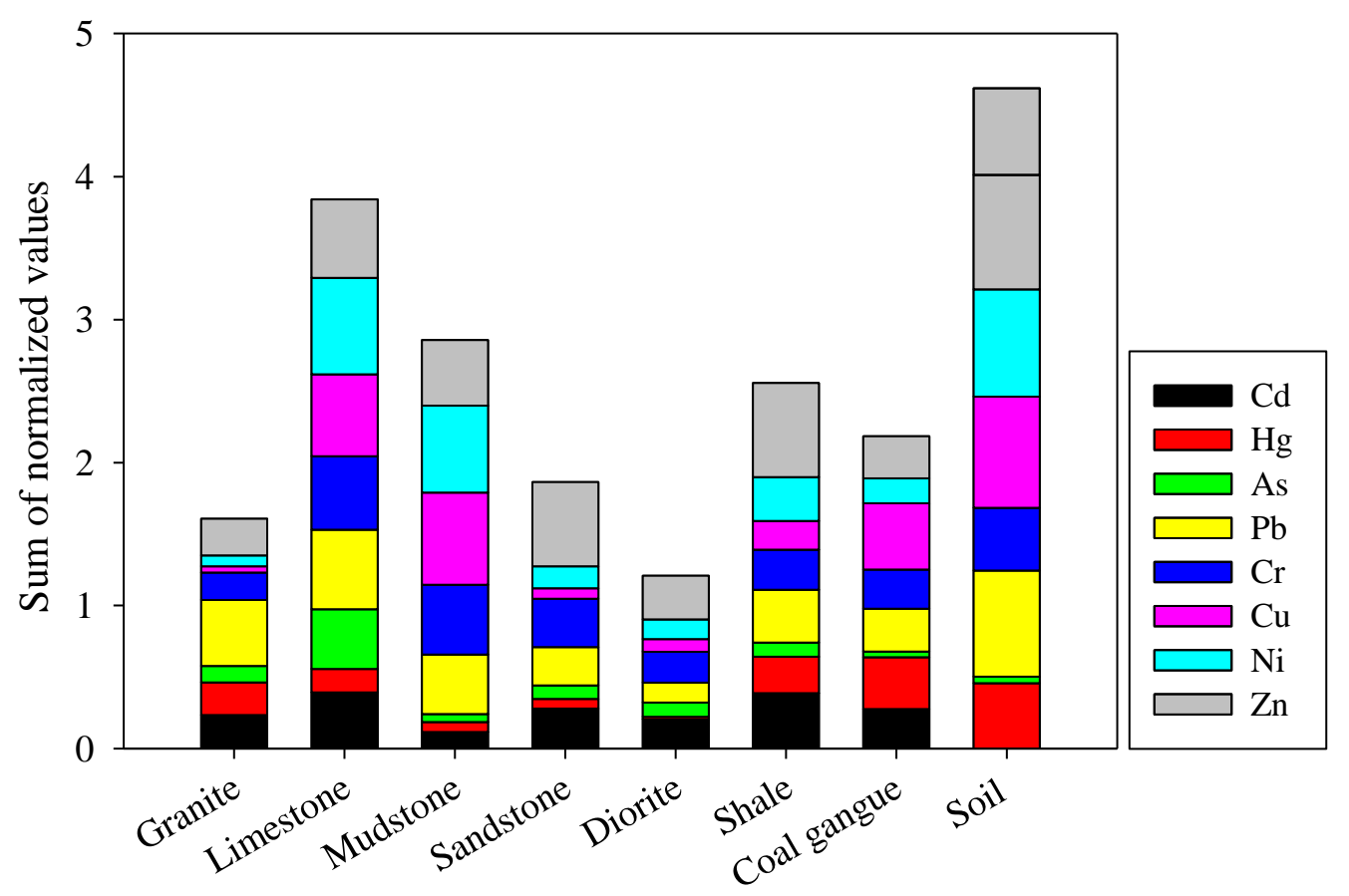

Figure 5. Heavy-metal spectral diagrams in different samples. To make the data comparable, heavymetal concentrations were normalized using the min-max scaling method.

As shown, the proportions of different heavy metals varied in different types of samples, which are characterized by the diagram height. Soil samples were found to have the highest sum of normalized value (4.62), with $\mathrm{Ni}, \mathrm{Cr}, \mathrm{Cu}$, and $\mathrm{As}$ contributing most to the sum-their contributions were $17.28 \%, 16.85 \%, 16.25 \%$, and $16.09 \%$, respectively. Limestone ranked second when considering the sum value (3.84), followed by mudstone (2.86) $>$ shale (2.56) $>$ coal gangue (2.19) $>$ sandstone (1.86) $>$ granite (1.61) $>$ diorite (1.21). The normalized values of most heavy metals in soil samples were also higher than in other samples. For example, the normalized values of $\mathrm{Cd}$, As, $\mathrm{Cr}, \mathrm{Ni}$, and $\mathrm{Zn}$ were 0.46 , $0.74,0.78,0.80$, and 0.61 , respectively. These values exceeded the corresponding values in other samples, implying the accumulation of heavy metals in soils [48]. Obviously, the accumulation of heavy metals in the soils of our study was not only related to rock and coal gangue, as they displayed diverse concentrations of heavy metals. Coal-related industrial activities and transport-vehicle emissions are possible anthropogenic sources [49]. However, the normalized values of $\mathrm{Hg}$ and $\mathrm{Pb}$ in soils were relatively low (0.045 and 0.44$)$, especially for $\mathrm{Hg}$, which only accounted for $12.5 \%$ of coal gangue $(0.36)$ and $17.72 \%$ of shale $(0.25)$, indicating these heavy metals in coal gangue and shale may transform into soils [12].

On the whole, the proportions of different heavy metals in soils were more similar in limestone, mudstone, and shale, implying soils might indirectly inherit their features from them through their parent material. As most heavy metals had lower concentrations in rock and gangue compared with soils, human activities such as agricultural production and industrial production, conducted before mining activities here, may also be contributing to the elevated heavy-metal concentrations in soils. Compared with soils, coal gangue and shale were more enriched with $\mathrm{Hg}$, and limestone and granite were more enriched with $\mathrm{Pb}$. During the practice of land reclamation, more attention should be paid to these types of rock. 


\section{Conclusions}

This study investigated the concentrations, potential ecological risk, and variations with depth and sample type of heavy metals in a large open-pit coal mine in China. Compared with soils, lower mean concentrations were found in rocks and coal gangues for most metals (except $\mathrm{Hg}$ ). Potential ecological risk assessment indicated that $\mathrm{As}, \mathrm{Pb}, \mathrm{Cr}, \mathrm{Cu}$, $\mathrm{Zn}$, and $\mathrm{Ni}$ showed low risk in all samples, while the ecological risk degrees of $\mathrm{Cd}$ and $\mathrm{Hg}$ were higher than other heavy metals. In the rock samples, limestone and shale also showed high $\mathrm{Cd}$ concentrations. The mean concentrations of $\mathrm{Cr}, \mathrm{Cu}$, and $\mathrm{Ni}$ in different samples were similar, with elevated concentrations in soils, limestone, and mudstone, and lower concentrations in granite and diorite. $\mathrm{As}, \mathrm{Pb}, \mathrm{Cr}, \mathrm{Cu}$, and $\mathrm{Ni}$ had more correlation pairs with each other, and $\mathrm{N}$ and $\mathrm{P}$ were found to be closely correlated with heavy metals. The proportions of different heavy metals in soils were more similar in limestone, mudstone, and shale, implying that soils might indirectly inherit their features from them through their parent material.

Author Contributions: Conceptualization, Z.B. and M.J.; methodology, M.J.; software, X.L.; validation, X.L., M.J. and Z.B.; formal analysis, Z.B.; investigation, X.L.; resources, Z.B.; data curation, X.L.; writing_original draft preparation, X.L.; writing—review and editing, X.L., M.J. and Z.B.; visualization, M.J.; supervision, M.J. and Z.B.; project administration, Z.B. All authors have read and agreed to the published version of the manuscript.

Funding: This research received no external funding.

Acknowledgments: The authors are extremely grateful to the editor and anonymous reviewers for their constructive comments.

Conflicts of Interest: The authors declare no conflict of interest.

\section{References}

1. Palmer, M.A.; Bernhardt, E.S.; Schlesinger, W.H.; Eshleman, K.N.; Foufoula-Georgiou, E.; Hendryx, M.S.; Lemly, A.D.; Likens, G.E.; Loucks, O.L.; Power, M.E.; et al. Science and regulation. Mountaintop mining consequences. Science 2010, 327, 148-149. [CrossRef]

2. Li, Z.; Ma, Z.; van der Kuijp, T.J.; Yuan, Z.; Huang, L. A review of soil heavy metal pollution from mines in China: Pollution and health risk assessment. Sci. Total Environ. 2014, 468-469, 843-853. [CrossRef]

3. Hardy, M.; Cornu, S. Location of natural trace elements in silty soils using particlesize fractionation. Geoderma 2006, 133, 295-308. [CrossRef]

4. $\quad$ Li, C.; Sanchez, G.M.; Wu, Z.; Cheng, J.; Zhang, S.; Wang, Q.; Li, F.; Sun, G.; Meentemeyer, R.K. Spatiotemporal patterns and drivers of soil contamination with heavy metals during an intensive urbanization period (1989-2018) in southern China. Environ. Pollut. 2020, 260, 114075. [CrossRef]

5. $\quad \mathrm{Wu}, \mathrm{J} . ; \mathrm{Li}$, J.; Teng, Y.; Chen, H.; Wang, Y. A partition computing-based positive matrix factorization (PC-PMF) approach for the source apportionment of agricultural soil heavy metal contents and associated health risks. J. Hazard. Mater. 2020, $388,121766$. [CrossRef] [PubMed]

6. He, S.; Lu, Q.; Li, W.; Ren, Z.; Zhou, Z.; Feng, X.; Zhang, Y.; Li, Y. Factors controlling cadmium and lead activities in different parent material-derived soils from the Pearl River Basin. Chemosphere 2017, 182, 509-516. [CrossRef]

7. Tashakor, M.; Hochwimmer, B.; Brearley, F.Q. Geochemical assessment of metal transfer from rock and soil to water in ser-pentine areas of Sabah (Malaysia). Environ. Earth Sci. 2017, 76, 1-13. [CrossRef]

8. Zinn, Y.L.; Faria, J.A.D.; Araujo, M.A.D.; Skorupa, A.L.A. Soil parent material is the main control on heavy metal concentrations in tropical highlands of Brazil. Catena 2020, 185, 104319. [CrossRef]

9. Kobielska, P.A.; Howarth, A.J.; Farha, O.K.; Nayak, S. Metal-organic frameworks for heavy metal removal from water. Coordin. Chem. Rev. 2018, 358, 92-107. [CrossRef]

10. Anda, M. Cation imbalance and heavy metal content of seven Indonesian soils as affected by elemental compositions of parent rocks. Geoderma 2012, 189-190, 388-396. [CrossRef]

11. Sun, R.; Sonke, J.E.; Liu, G.; Zheng, L.; Wu, D. Variations in the stable isotope composition of mercury in coal-bearing sequences: Indications for its provenance and geochemical processes. Int. J. Coal Geol. 2014, 133, 13-23. [CrossRef]

12. Tang, Q.; Li, L.; Zhang, S.; Zheng, L.; Miao, C. Characterization of heavy metals in coal gangue-reclaimed soils from a coal mining area. J. Geochem. Explor. 2018, 186, 1-11. [CrossRef]

13. Zhou, Y.; Aamir, M.; Liu, K.; Yang, F.; Liu, W. Status of mercury accumulation in agricultural soil across China: Spatial dis-tribution, temporal trend, influencing factor and risk assessment. Environ. Pollut. 2018, 240, 116-124. [CrossRef]

14. Kumar, A.; Pinto, M.C.; Candeias, C.; Dinis, P.A. Baseline maps of potentially toxic elements in the soils of Garhwal Himalayas, India: Assessment of their eco-environmental and human health risks. Land Degrad. Dev. 2021, 32, 3856-3869. [CrossRef] 
15. Kumar, A.; Jigyasu, D.K.; Kumar, A.; Subrahmanyam, G.; Mondal, R.; Shabnam, A.A.; Cabral-Pinto, M.; Malyan, S.K.; Cha-turvedi, A.K.; Gupta, D.K.; et al. Nickel in terrestrial biota: Comprehensive review on contamination, toxicity, tolerance and its remediation approaches. Chemosphere 2021, 275, 129996. [CrossRef] [PubMed]

16. Lu, R.K. Analytical Methods of Soil Agro-Chemistry; China Agriculture Science Technology Press: Beijing, China, 2000; pp. 146-203.

17. Liu, X.; Shi, H.; Bai, Z.; Zhou, W.; Liu, K.; Wang, M.; He, Y. Heavy metal concentrations of soils near the large opencast coal mine pits in China. Chemosphere 2020, 244, 125360. [CrossRef] [PubMed]

18. Hakanson, L. An ecological risk index for aquatic pollution control. A sedimentological approach. Water Res. 1980, 14, 975-1001. [CrossRef]

19. Li, F.; Zhang, J.; Liu, C.; Xiao, M.; Wu, Z. Distribution, bioavailability andprobabilistic integrated ecological risk assessment of heavy metals in sedimentsfrom Honghu Lake, China. Process. Saf. Environ. Prot. 2018, 116, 169-179. [CrossRef]

20. Yu, R.; Hu, G.; Wang, L. Speciation and ecological risk of heavy metals in intertidal sediments of Quanzhou Bay, China. Environ. Monit. Assess. 2010, 163, 241-252. [CrossRef]

21. Suresh, G.; Ramasamy, V.; Meenakshisundaram, V.; Venkatachalapathy, R.; Ponnusamy, V. Influence of mineralogical and heavy metal composition on natural radionuclide concentrations in the river sediments. Appl. Radiat. Isotopes 2011, 69, 1466-1474. [CrossRef] [PubMed]

22. Wang, X.; Zhou, Q.; Ren, L. Agricultural Products Quality in Mineral Area and Behaviors of Heavy Metals in Soil—Rock In-terface. J. Agro-Environ. Sci. 2004, 23, 459-463.

23. Ge, G. Trace elements in coal rock in Shanxi and their impact on the environment. Coal Geol. China 1996, 8, 58-62.

24. Bini, C.; Sartori, G.; Wahsha, M.; Fontana, S. Background levels of trace elements and soil geochemistry at regional level in NE Italy. J. Geochem. Explor. 2011, 109, 125-133. [CrossRef]

25. Melo, V.F.; Buschle, B.; Souza, L.C.P.; Bonfleur, E.J. Reference values for potentially harmful elements in soils from Atlantic Rainforest, Brazil. J. Geochem. Explor. 2017, 181, 138-147. [CrossRef]

26. Huang, J.; Peng, S.; Mao, X.; Li, F.; Guo, S.; Shi, L.; Shi, Y.; Yu, H.; Zeng, G. Source apportionment and spatial and quantitative ecological risk assessment of heavy metals in soils from a typical Chinese agricultural county. Process. Saf. Environ. 2019, 126, 339-347. [CrossRef]

27. Ni, S.Q.; Ju, Y.W.; Hou, Q.L.; Wang, S.J.; Xiao, L.L.; Liu, Q.; Wu, Y.D. The comparison of the role of iron oxides in the migration and weathering of heavy metal elements and the enrichment of heavy metal elements in carbonate rocks. Prog. Nat. Sci. 2009, 61-68.

28. Jiang, X.; Lu, W.X.; Zhao, H.Q.; Yang, Q.C.; Yang, Z.P. Potential ecological risk assessment and prediction of soil heavy-metal pollution around coal gangue dump. Nat. Hazard. Earth Sys. 2014, 14, 1599. [CrossRef]

29. Kumar, V.; Sharma, A.; Kaur, P.; Singh Sidhu, G.P.; Bali, A.S.; Bhardwaj, R.; Thukral, A.K.; Cerda, A. Pollution assessment of heavy metals in soils of India and ecological risk assessment: A state-of-the-art. Chemosphere 2019, 216, 449-462. [CrossRef] [PubMed]

30. Lin, W.; Wu, K.; Lao, Z.; Hu, W.; Lin, B.; Li, Y.; Fan, H.; Hu, J. Assessment of trace metal contamination and ecological risk in the forest ecosystem of dexing mining area in northeast Jiangxi Province, China. Ecotoxicol. Environ. Saf. 2019, 167, 76-82. [CrossRef]

31. Feng, Y.; Bao, Q.; Yunpeng, C.; Lizi, Z.; Xiao, X. Stochastic potential ecological risk model for heavy metal contamination in sediment. Ecol. Indic. 2019, 102, 246-251. [CrossRef]

32. Zhu, A.; Liu, J.; Qiao, S.; Zhang, H. Distribution and assessment of heavy metals in surface sediments from the Bohai Sea of China Mar. Pollut. Bull. 2020, 153, 110901. [CrossRef]

33. Cheng, H.; Li, M.; Zhao, C.; Yang, K.; Li, K.; Peng, M.; Yang, Z.; Liu, F.; Liu, Y.; Bai, R.; et al. Concentrations of toxic metals and ecological risk assessment for sediments of major freshwater lakes in China. J. Geochem. Explor. 2015, 157, 15-26. [CrossRef]

34. Lin, Q.; Liu, E.; Zhang, E.; Li, K.; Shen, J. Spatial distribution, contamination and ecological risk assessment of heavy metals in surface sediments of Erhai Lake, a large eutrophic plateau lake in southwest China. Catena 2016, 145, 193-203. [CrossRef]

35. Deng, M.; Yang, X.; Dai, X.; Zhang, Q.; Malik, A.; Sadeghpour, A. Heavy metal pollution risk assessments and their transportation in sediment and overlay water for the typical Chinese reservoirs. Ecol. Indic. 2020, 112, 106166. [CrossRef]

36. Zhao, F.; Ma, Y.; Zhu, Y.; Tang, Z.; McGrath, S.P. Soil Contamination in China: Current Status and Mitigation Strategies. Environ. Sci. Technol. 2015, 49, 750-759. [CrossRef]

37. He, T.B.; Dong, L.L.; Liu, Y.S.; Shu, Y.G.; Luo, H.B.; Liu, F. Change of physical-chemical properties and heavy mental element in soil from different parent material/rock. J. Soil Water Conserv. 2006, 6, 157-162.

38. Zhu, H.; Bing, H.; Wu, Y.; Zhou, J.; Sun, H.; Wang, J.; Wang, X. The spatial and vertical distribution of heavy metal contamination in sediments of the Three Gorges Reservoir determined by anti-seasonal flow regulation. Sci. Total Environ. 2019, 664, 79-88. [CrossRef] [PubMed]

39. Niu, X.; Guo, S.; Gao, L.; Cao, Y.; Wei, X. Mercury Release during Thermal Treatment of Two Coal Gangues and Two Coal Slimes under N2 and in Air. Energy Fuel 2017, 31, 8648-8654. [CrossRef]

40. Oyeyemi, K.D.; Aizebeokhai, A.P.; Okagbue, H.I. Geostatistical exploration of dataset assessing the heavy metal contamination in Ewekoro limestone, Southwestern Nigeria. Data Brief 2017, 14, 110-117. [CrossRef] [PubMed]

41. Fang, X.; Peng, B.; Wang, X.; Song, Z.; Zhou, D.; Wang, Q.; Qin, Z.; Tan, C. Distribution, contamination and source identification of heavy metals in bed sediments from the lower reaches of the Xiangjiang River in Hunan province, China. Sci. Total Environ. 2019, 689, 557-570. [CrossRef]

42. Zhang, J.; Yang, R.; Li, Y.C.; Peng, Y.; Wen, X.; Ni, X. Distribution, accumulation, and potential risks of heavy metals in soil and tea leaves from geologically different plantations. Ecotoxicol. Environ. Saf. 2020, 195, 110475. [CrossRef] 
43. Qiao, J.; Zhu, Y.; Jia, X.; Shao, M.; Niu, X.; Liu, J. Distributions of arsenic and other heavy metals, and health risk assessments for groundwater in the Guanzhong Plain region of China. Environ. Res. 2020, 181, 108957. [CrossRef] [PubMed]

44. Bian, F.; Zhong, Z.; Zhang, X.; Yang, C. Phytoremediation potential of moso bamboo (Phyllostachys pubescens) intercropped with Sedum plumbizincicola in metal-contaminated soil. Environ. Sci. Pollut. Res. Int. 2017, 24, 27244-27253. [CrossRef] [PubMed]

45. Zhao, K.; Zhang, L.; Dong, J.; Wu, J.; Ye, Z.; Zhao, W.; Ding, L.; Fu, W. Risk assessment, spatial patterns and source apportionment of soil heavy metals in a typical Chinese hickory plantation region of southeastern China. Geoderma 2020, 360, 114011. [CrossRef]

46. Zaharescu, D.G.; Hooda, P.S.; Soler, A.P.; Fernandez, J.; Burghelea, C.I. Trace metals and their source in the catchment of the high altitude Lake Respomuso, Central Pyrenees. Sci. Total Environ. 2009, 407, 3546-3553. [CrossRef] [PubMed]

47. Ma, Y.; Wang, Y.; Chen, Q.; Li, Y.; Guo, D.; Nie, X.; Peng, X. Assessment of heavy metal pollution and the effect on bacterial community in acidic and neutral soils. Ecol. Indic. 2020, 117, 106626. [CrossRef]

48. Sun, L.; Guo, D.; Liu, K.; Meng, H.; Zheng, Y.; Yuan, F.; Zhu, G. Levels, sources, and spatial distribution of heavy metals in soils from a typical coal industrial city of Tangshan, China. Catena 2019, 175, 101-109. [CrossRef]

49. Liang, J.; Feng, C.; Zeng, G.; Gao, X.; Zhong, M.; Li, X.; Li, X.; He, X.; Fang, Y. Spatial distribution and source identification of heavy metals in surface soils in a typical coal mine city, Lianyuan, China. Environ. Pollut. 2017, 225, 681-690. [CrossRef] 